\title{
Water quantity investigation of simulated green roofs in a tropical climate: influence of vegetation composition
}

\section{Investigação da quantidade de água de telhados verdes simulados em um clima tropical: influência da composição da vegetação}

\author{
${ }^{1}$ Thaisa Camila Vacari, ${ }^{2}$ Jocilan Rodrigues Lara, ${ }^{3}$ Zoraidy Marques de Lima, ${ }^{4}$ Eduardo Beraldo de Morais \\ ${ }^{1}$ Mestre em Recursos Hídricos: Manejo e Conservação, Universidade Federal de Mato Grosso - UFMT \\ (thaisavacari@gmail.com) \\ ${ }^{2}$ Engenheiro Sanitarista e Ambiental, Universidade Federal de Mato Grosso - UFMT \\ (jocilanlara@hotmail.com). \\ ${ }^{3}$ Doutora em Microbiologia, Professora do Programa de Pós-Graduação em Recursos Hídricos, Universidade \\ Federal de Mato Grosso - UFMT (zoraidy@ terra.com.br). \\ ${ }^{4}$ Doutor em Microbiologia Aplicada, Professor do Departamento de Engenharia Sanitária e Ambiental e do \\ Programa de Pós-Graduação em Recursos Hídricos, Universidade Federal de Mato Grosso - UFMT \\ (beraldo_morais@yahoo.com.br).
}

\begin{abstract}
Green roofs are recognized as a sustainable infrastructure to improve the environmental quality of cities. Among many benefits, green roofs reduce the rate and volume of runoff helping to improve rainwater management. This study investigated the runoff retention capacity of three pilot extensive green roof assemblies with different vegetation (grass, shrub and intercropping of the two plants). Rainwater runoff data were collected for 18 rainfall events that ranged from a minimum of $1.6 \mathrm{~mm}$ to a maximum of $157.9 \mathrm{~mm}$. Average precipitation event retention efficiencies were $46.7,59.7$ and $61.6 \%$ for intercropped, shrub and grass green roofs, respectively, while the annual runoff retention rates were $43.8,57.3$ and $59.7 \%$. The difference in retention rates for the green roofs with different vegetation was not statistically significant. The rainfall intensity influenced the retention rates, with the highest retentions for small events $(<10.0 \mathrm{~mm})$ followed by medium $(10.0-24.9 \mathrm{~mm})$. Retention was found to correspond significantly to rainfall depths. On the other hand, regression analysis failed to provide a relationship between retention and antecedent dry weather period (ADWP). The organic soil used as substrate appears to be the deciding factor for rainwater retention.
\end{abstract}

Keywords: Organic Substrate. Rainwater Management. Runoff Retention. Grass. Shrub.

RESUMO: Telhados verdes são reconhecidos como uma infraestrutura sustentável que melhoram a qualidade ambiental nas cidades. Entre muitos benefícios, os telhados verdes reduzem a taxa e o volume do escoamento superficial, contribuindo no gerenciamento das águas pluviais. Este estudo investigou a capacidade de retenção do escoamento de três conjuntos pilotos de telhados verdes extensivos com diferentes tipos de vegetação (gramínea, arbusto e consórcio entre as duas plantas). Os dados de escoamento de águas pluviais pelos telhados verdes foram coletados em 18 eventos de chuva que variaram de $1,6 \mathrm{~mm}$ a $157,9 \mathrm{~mm}$. As eficiências médias de retenção da precipitação foram de 46,7, 59,7 e 61,6\% para os telhados verdes consorciados, arbustivos e com gramínea, respectivamente, enquanto as taxas anuais de retenção de escoamento foram de 43,8, 57,3 e 59,7\%. Não houve diferença estatística significativa para as taxas de retenção dos telhados verdes com diferentes tipos de vegetações. A intensidade da precipitação influenciou as taxas de retenção, sendo as maiores retenções observadas para eventos fracos $(<10,0 \mathrm{~mm})$ seguidas por eventos médios $(10,0-24,9 \mathrm{~mm})$. A retenção está diretamente ligada à intensidade do evento chuvoso. Por outro lado, a análise de regressão não forneceu uma relação entre a retenção e o período de tempo seco anterior (PTSA). O solo orgânico usado como substrato parece ser o fator decisivo para a retenção de água da chuva.

Palavras-chave: Substrato Orgânico. Manejo de Águas Pluviais. Retenção do Escoamento. Grama. Arbusto.

\section{INTRODUCTION}

Many of the environmental impacts of urbanization are a consequence of increase of the impermeable surfaces areas, which excessively raises runoff, erosion and risk of floods. Furthermore, when green areas are replaced by impermeable surfaces, a decrease in canopy interception and transpiration within the city are observed and this leads to increased temperature and decreased air humidity (BERNDTSSON, 2010). As a solution to these 
problems, green infrastructure approaches based on natural systems have been developed and implemented to improve the environmental quality of cities (TZOULAS et al., 2007).

Green roofs (also called living roofs, vegetated roofs or eco-roofs) are an example of green infrastructure. These green systems strategically integrate vegetation, easily drain soils and provide natural storage into urban landscape, so that rainfall can be treated, stored and evapotranspired to avoid excess rainwater runoff in urban impermeable surfaces (HARPER $e t$ al., 2015; BUCKLAND-NICKS et al., 2016; CATALANO et al., 2016; BESIR \& CUCE, 2018). Furthermore, other interesting benefits of green roofs also have been reported, as decreased building energy consumption (PARIZOTTO \& LAMBERTS, 2011), improved air quality and building aesthetics (YANG et al., 2008), minimized urban heat island effect (FANG, 2008) and reduced noise level (Van RENTERGHEM \& BOTTELDOOREN, 2009). Germany, Sweden, USA, Japan and Singapore recognized these benefits and started encouraging or even imposing the use of green roofs in buildings (VIJAYARAGHAVAN \& RAJA, 2014). Recently, in Brazil, cities as Porto Alegre, Recife, Rio de Janeiro and São Paulo have approved specific legislation to encourage the application of green roofs.

Typically, the construction of green roofs involves multiple layers of materials, including a drainage material, a filter to prevent the loss of soil particles, a soil substrate and vegetation. Depending on the type of construction of the roof, green roofs are categorized in three main categories: extensive, intensive and semi-intensive. An extensive green roof is constructed with a substrate that is less than $15 \mathrm{~cm}$ deep and suitable for large rooftops (HASHEMI et al., 2015). Because of shallow media layer, extensive green roofs are planted or sown with grasses, herbs, succulents, and mosses and require low maintenance. Intensive green roofs consist of a more than $20 \mathrm{~cm}$ thick substrate and are designed as gardens, supporting bigger plants such as trees and bushes, and require weeding, fertilizing, and watering (BERNDTSSON et al., 2009). Semi-intensive green roofs show intermediate characteristics.

Several studies on the hydrological properties of green roofs have shown a range of average rainwater retention efficiencies (Table 1). The prominent differences observed between extensive green roofs retention values can be attributed to the slope of the green roof (CATALANO et al., 2016), the type and depth of the substrate used (LEE et al., 2015; BUCKLAND-NICKS et al., 2016), green roof design (VANUYTRECHT et al., 2014), characteristics of rain events (intensity and duration) (VOLDER \& DVORAK, 2014; ZHANG et al., 2015), weather conditions, climate and season (BERNDTSSON, 2010; WONG \& JIM, 2015). In addition to these factors, vegetation composition also has an important influence on green roof hydrological performance. According to Dunnett et al. (2008), vegetation can influence through interception and evaporation of rainfall by vegetation canopy and plant surfaces, through uptake and storage of water in plant tissues, and through transpiration of water from the plant back to the atmosphere.

The studies mentioned above have demonstrated that green roof runoff reductions are understandably variable mainly due to the countless possibilities to construct a green roof. This fact highlights the importance of continuous research on quantifying runoff from green roofs. In the present study, the runoff retention by three pilot-scale green roof assemblies with different vegetation (grass, shrub and intercropping of the two plants), constructed and operated on a real roof in an urban setting, was assessed. Moreover, predictive relationships between rainfall characteristics (rainfall depth, rainfall duration, antecedent dry weather period (ADWP)) and green roof retention were also established. 
Vacari, Thaisa, et al.; Water quantity investigation of simulated green roofs in a tropical climate: influence of vegetation composition. E\&S Engineering and Science, 2019, 8:2.

Table 1 - Retention efficiencies (\%) reported in various studies on extensive green roofs

\begin{tabular}{|c|c|c|}
\hline Reference & $\begin{array}{l}\text { Retention efficiency } \\
\text { observed }(\%)\end{array}$ & Location \\
\hline Voyde et al. (2010) & 82.0 & Auckland, New Zealand \\
\hline Getter et al. (2007) & 80.2 & Detroit, USA \\
\hline Volder \& Dvorak (2014) & 78.0 & College Station, USA \\
\hline Zhang et al. (2015) & 77.2 & Chongqing, China \\
\hline Nawaz et al. (2015) & 66.0 & Leeds, England \\
\hline Villarreal \& Bengtsson (2005) & $\begin{array}{l}45.7 \\
36.5 \\
23.3\end{array}$ & Lund, Sweden \\
\hline Carson et al. (2013) & $\begin{array}{l}36.0 \\
47.0 \\
61.0\end{array}$ & New York, USA \\
\hline Lee et al. (2015) & $\begin{array}{l}27.1 \\
50.3\end{array}$ & Seoul, South Korea \\
\hline Harper et al. (2015) & 60.0 & Missouri, USA \\
\hline Stovin et al. (2012) & 42.7 & Sheffield, United Kingdom \\
\hline Gregoire \& Clausen (2011) & 41.6 & Storrs, USA \\
\hline Beck et al. (2011) & $\begin{array}{l}17.8 \\
21.1\end{array}$ & Portland, USA \\
\hline Spolek (2008) & $\begin{array}{l}12.0 \\
17.0 \\
25.0\end{array}$ & Portland, USA \\
\hline Beecham \& Razzaghmanesh (2015) & $\begin{array}{l}79.6 \\
78.1 \\
63.7 \\
65.1\end{array}$ & Adelaide, Australia \\
\hline Razzaghmanesh \& Beecham (2014) & 74.0 & Adelaide, Australia \\
\hline
\end{tabular}

\section{MATERIALS AND METHODS}

\subsection{Study site}

The study site was located in Federal University of Mato Grosso (FUMT), Cuiabá city, Mato Grosso State, which is located at Midwest region of Brazil. Local climate, as well as in most of Brazil, is tropical. According to rainfall data from 1989 to 2015, obtained from Mestre Bombled meteorological station located approximately $100 \mathrm{~m}$ from the site of the experiments, the mean annual precipitation at Cuiabá was $1405.3 \mathrm{~mm}$. However, a strong seasonality in the precipitation regime was observed with a rainy season (October to April) and a dry season (May to September) (Figure 1). The rainiest months were January, February and March. 
Figure 1 - Average monthly rainfall in Cuiabá, Brazil (1989-2015)

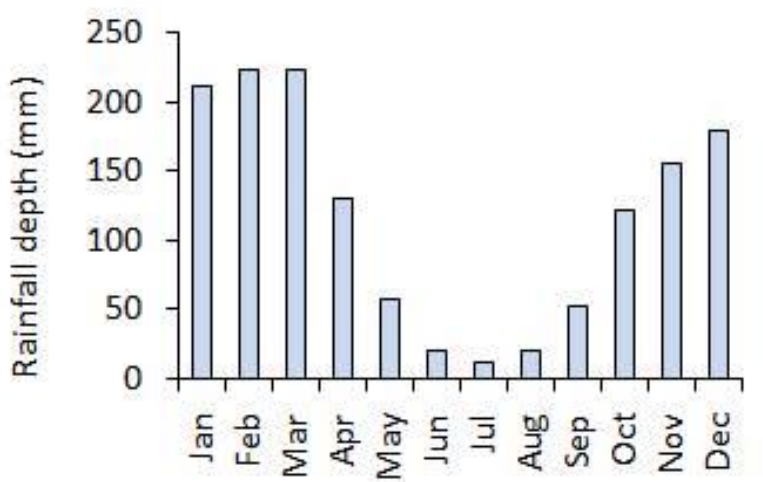

Source: Mestre Bombled meteorological station

\subsection{Experimental designs}

Extensive green roof experimental modules were assembled using plastic trays $(0.4 \mathrm{~m}$ wide $\times 0.6 \mathrm{~m}$ long) with the same principle as full-scale vegetated roofs. All modules were placed on a $4^{\circ}$ slope to simulate common roof design. The standard green roof module consisted of drainage layer, filter layer, soil substrate, and vegetation (Figure 2). Each one also had a $25 \mathrm{~mm}$ diameter drain hole that directed all runoff into a capture container. The drainage layer was $5 \mathrm{~cm}$ thick of expanded clay. The filter layers were in form of a geotextile (membrane material, grammage $=200 \mathrm{~g} / \mathrm{m}^{2}$ ), which prevented small particle from being washed from the substrate layer to the drainage layer. The soil substrate was composed of a mixture of $90 \%$ commercial organic soil and $10 \%$ vermiculite. Zoysia japonica (grass) and Ixora coccinea (shrub) were select for the study because they are abundantly used as ornamental plants in gardens of Cuiabá, which indicates that they are adapted to the climatic conditions. Two trays were planted with twelve plugs of Ixora coccinea (4 rows x 3 columns) each, equidistantly spaced among themselves and the tray edges. The plugs were of uniform size (approximate height $7 \mathrm{~cm}$ ). In other two trays, Zoysia japonica were planted as a continuous mat over the entire soil surface. The same procedures were used to plant two green roof modules with both plants. Thus, there were six green roof modules in this study, consisting of two of each of the three roof types. For the purpose of adaptation, artificial watering was provided every three days. Field experiments started after three months of plant adaptation. The green roof modules were arranged in an alternating sequence on the roof of the Faculty of Architecture, Engineering and Technology (15 36'29,27"S and 56 $\left.{ }^{\circ} 32,80^{\prime \prime} \mathrm{W}\right)$. They were positioned $1.4 \mathrm{~m}$ above the school building roof. The modules were completely free of shading.

The quantity of runoff from each green roof modules was measured using a beaker with graduation scale $( \pm 5 \mathrm{ml})$. The monitoring took place over a period of three months (January-March 2015). In this period, 42 rainfall events were recorded. However, rainfall events less $1.5 \mathrm{~mm}$ and that did not produced runoff were excluded from event-based analysis. 


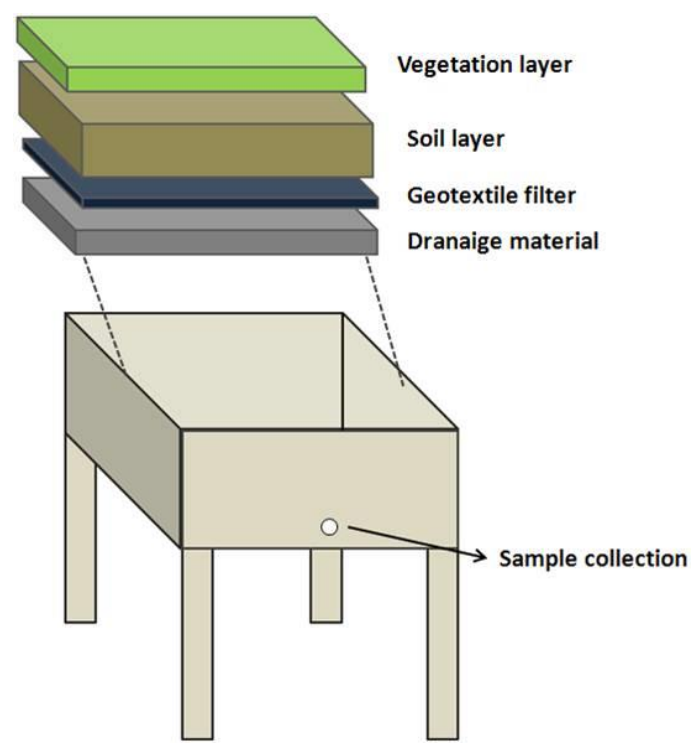

\subsection{Data analysis}

Runoff retention rates from green roof modules were calculated by equations 1 and 2 (Zhang et al., 2015):

$$
\begin{gathered}
\text { Retetion } \operatorname{Rate}(\%)=\frac{R V-R}{R V} \times 100 \\
R V=P \times A
\end{gathered}
$$

where $R V$ is the rainfall volume actually received by the green roof $(\mathrm{L}) ; R$ is the runoff depth of the green roof $(\mathrm{L}) ; P$ is precipitation $(\mathrm{mm}) ; A$ is the area of the green roof $\left(\mathrm{m}^{2}\right)$.

The differences in runoff retention rates from the three green roof modules were evaluated using the nonparametric Kruskal-Wallis test (at 5\% significance level), as the data failed to meet the assumption of normality and homogeneity of variances, even after data transformations. Regression analysis were also undertaken to develop predictive relationships between rainfall characteristics (rainfall depth, rainfall duration, ADWP) and green roof retention. The correlation strength was indicated by the coefficient of determination $\left(\mathrm{R}^{2}\right)$.

\subsection{Annual runoff retention rates}

The rainfall data from 1989 to 2015, representative of the site where green roofs were installed, and the results of the green roofs runoff retention were statistically analyzed at different rainfall intensities to calculate the annual runoff retention rates for the green roof modules (Table 3). 


\section{RESULTS AND DISCUSSION}

\subsection{Rainfall retention}

In the eighteen rainfall events quantified during the study period, precipitation ranged from 1.6 to $157.9 \mathrm{~mm}$, and were included in the analysis, with a variety of different characteristics (Table 2). On the I. coccinea green roof the rainfall retention rate ranged from 8.5 to $100 \%$, with an average retention rate of $59.7 \%$, while on the Z. japonica green roof the retention rate ranged from 34.5 to $100 \%$, with an average of $61.6 \%$. On the intercropped green roof the rainfall retention rate ranged from 4.7 to $100 \%$, with an average retention rate of $46.7 \%$.

Table 2 - Precipitation data and hydrological characteristics of green roofs

\begin{tabular}{|c|c|c|c|c|c|c|c|}
\hline \multirow{2}{*}{$\begin{array}{l}\text { Rainfall } \\
\text { events }\end{array}$} & \multirow{2}{*}{$\begin{array}{l}\text { Precipitation } \\
(\mathrm{mm})\end{array}$} & \multicolumn{3}{|c|}{ Runoff (mm) } & \multicolumn{3}{|c|}{ Retention rate $(\%)$} \\
\hline & & $\begin{array}{l}I . \\
\text { coccinea } \\
\text { (shrub) }\end{array}$ & $\begin{array}{l}Z . \\
\text { japonica } \\
\text { (grass) }\end{array}$ & Intercropping & $\begin{array}{l}\text { I. coccinea } \\
\text { (shrub) }\end{array}$ & $\begin{array}{l}Z . \\
\text { japonica } \\
\text { (grass) }\end{array}$ & Intercropping \\
\hline $14 / 01 / 2015$ & 21.6 & 3.13 & 9.38 & 1.25 & 85.5 & 56.6 & 94.2 \\
\hline 26/01/2015 & 5.0 & 0.00 & 0.00 & 0.00 & 100.0 & 100.0 & 100.0 \\
\hline $02 / 02 / 2015$ & 18.9 & 11.63 & 8.88 & 17.50 & 38.4 & 53.0 & 7.3 \\
\hline $11 / 02 / 2015$ & 66.8 & 20.25 & 12.13 & 28.00 & 69.7 & 81.8 & 58.1 \\
\hline $16 / 02 / 2015$ & 15.4 & 0.44 & 2.75 & 1.25 & 97.2 & 82.1 & 91.9 \\
\hline $18 / 02 / 2015$ & 44.7 & 21.19 & 22.31 & 31.06 & 52.6 & 50.1 & 30.5 \\
\hline 20/02/2015 & 157.9 & 141.00 & 103.38 & 141.88 & 10.7 & 34.5 & 10.1 \\
\hline $21 / 02 / 2015$ & 30.8 & 28.13 & 19.25 & 29.13 & 8.5 & 37.4 & 5.3 \\
\hline $23 / 02 / 2015$ & 24.5 & 12.88 & 11.63 & 19.00 & 47.4 & 52.6 & 22.4 \\
\hline $27 / 02 / 2015$ & 37.0 & 19.13 & 17.75 & 32.00 & 48.3 & 52.0 & 13.5 \\
\hline 02/03/2015 & 9.4 & 0.70 & 1.13 & 1.00 & 92.5 & 88.0 & 89.3 \\
\hline 03/03/2015 & 2.8 & 0.00 & 0.19 & 0.19 & 100.0 & 93.3 & 93.3 \\
\hline $13 / 03 / 2015$ & 1.6 & 0.14 & 0.50 & 0.69 & 91.2 & 68.0 & 56.0 \\
\hline $18 / 03 / 2015$ & 39.5 & 8.50 & 10.00 & 12.25 & 78.5 & 74.7 & 69.0 \\
\hline $24 / 03 / 2015$ & 53.4 & 20.25 & 26.13 & 33.63 & 62.1 & 51.1 & 37.0 \\
\hline 26/03/2015 & 59.0 & 41.06 & 27.25 & 43.25 & 30.4 & 53.8 & 26.7 \\
\hline 27/03/2015 & 6.8 & 4.25 & 4.25 & 4.69 & 37.0 & 37.0 & 30.6 \\
\hline $30 / 03 / 2015$ & 32.2 & 24.13 & 18.25 & 30.69 & 25.0 & 43.3 & 4.7 \\
\hline
\end{tabular}

The results from our tests fall within the range reported in the literature. The average retentions of 59.7 and $61.6 \%$ for shrub and grass green roofs were higher than the average of $50.9 \%$ obtained in fifteen studies with extensive green roofs presented in Table 1, while the average retention for intercropped green roof (46.7\%) was lower. Nevertheless, direct comparisons with other studies are limited given the large number of unique variables that influence the retention efficiency, including vegetation, slope, ADWP, climate and green roof media composition (NAWAZ et al., 2015).

The species of plants are an important factor affecting retention capacity of green roofs. Plants with developed foliage and root systems, such as grasses, have been shown to be more effective in reducing surface runoff (DUNNETT et al. 2008). Nagase and Dunnett (2012) showed that the highest water capture was observed in grasses, followed by forbs and sedum. This is also consistent with previous research of Lundholm et al. (2010), which showed that the highest water capture was observed in grasses, followed by tall forbs, creeping forbs and succulents. In our study, however, differences in retention rates between three types of green roofs (grass, shrub and intercropping of the two plants) were not significant $(p=0.2908)$. On the order hand, it is also likely that other factors are decisive in the 
retention capacity of green roofs. It has been shown that growing media composition (substrate), rather than vegetation type, can determine the water retention capacity (MONTERUSSO et al., 2004). Dunnet et al. (2008) found inconsistent results in two experiments to identify the relative contribution of soil and vegetation to runoff values, with bare soils resulting in both the highest and the lowest runoff reduction compared to treatment with plants. These results were debated as a result of the different organic matter content of soils. High organic matter content of substrate increases its water holding capacity, contributing to high retention (SPEAK et al. 2013). Buccola \& Spolek (2011) found that increased green roof soil depth improved water retention and runoff lagtime, but plant type does not seem to have a significant effect on either discharge quantity. Therefore, plant selection can be based on other factors, such as energy transfer, plant hardiness, and aesthetics. VanWoert et al. (2005) also claimed that the effects of vegetation on rainfall retention is minimal relative to the effects of growing media. The substrate used in our study was a commercial organic soil and it is likely that it had more influence in rainfall retention than type and composition of vegetation.

\subsection{Regression analysis}

A strong relationship between rainfall depth and runoff ( $p<0.00001$, Figure 3$)$ was observed for three types of green roofs. The runoff on green roofs with $Z$. japonica was generally lower than on green roofs with I. coccinea and intercropping. This is indicated by regression line slopes of 0.61 on grass green roof and 0.84 and 0.86 on shrub and intercropped green roofs, respectively. Nevertheless, differences in runoff volume between three types of green roofs were not significant $(\mathrm{p}=0.5512)$. The relationship between rainfall depth and runoff is also shown in terms of percentage of retention (Figure 4). There was a significant inverse relationship (at 5\% significance level) between retention rate and rainfall depth for three green roofs. Numerous studies have reported similar results to this study (SIMMONS et al., 2008; RAZZAGHMANESH \& BEECHAM, 2014; NAWAZ et al., 2015; ZHANG et al., 2015).

A negative correlation was also apparent between retention and rainfall duration (Figure 5), although this was not deemed statistically significant for grass $(p=0.1000)$ and intercropped $(p=0.1615)$ green roofs. The scatter plots for retention and ADWP (Figure 6) show a large amount of scattering. Linear and non-linear (exponential, logarithmic and power) regressions were attempted, though they all resulted in poor $\mathrm{R}^{2}$ and no significance. Low ADWPs often result in low retention; however, a high ADWP does not guarantee high retention due to the finite retention capacity of the roof and the influence of weather conditions, which could increase evaporation rates during the ADWP (STOVIN et al., 2012). Although this study was conducted in summer (January to March), when the highest evaporation rates are expected, this is the rainy period in the study site. During all study period (75 days), 42 rainfall events were recorded and the ADWPs were short, not exceeding five days (results not shown). This may have influenced the large amounts of scattering in regression plots for retention and ADWP. On the order hand, the results imply that green roofs modules can make a significant contribution to the mitigation of rainwater runoff associated with high frequency rainfall events. 
Vacari, Thaisa, et al.; Water quantity investigation of simulated green roofs in a tropical climate: influence of vegetation composition. E\&S Engineering and Science, 2019, 8:2.

Figure 3 - Regression plot of rainfall depth and runoff for (a) I. coccinea green roof, (b) Z. japonica green roof and (c) consortium green roof
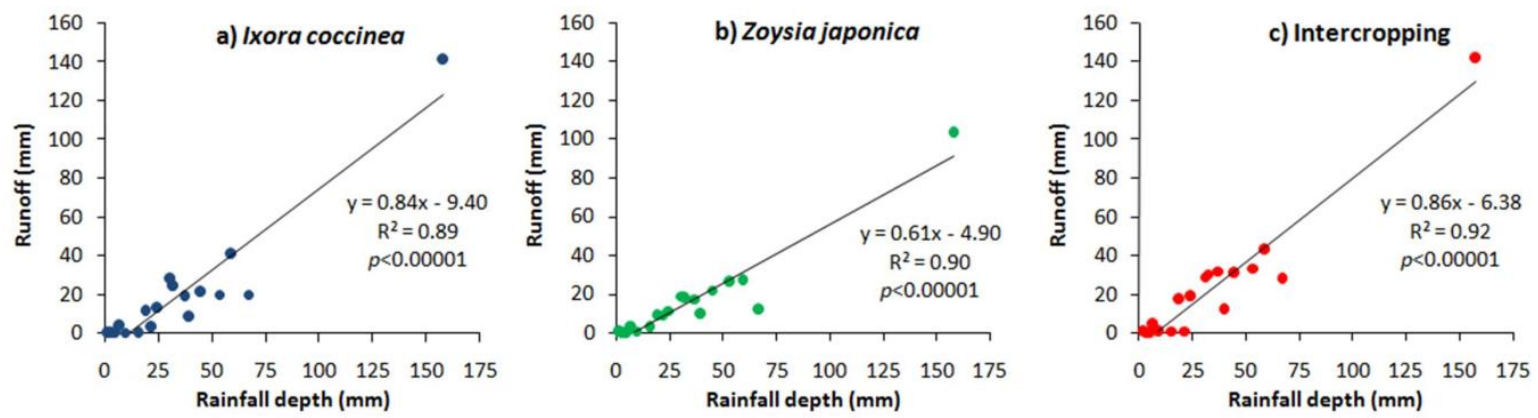

Figure 4 - Regression plot of rainfall depth and retention rate (\%) for (a) I. coccinea green roof, (b) Z. japonica green roof and (c) consortium green roof
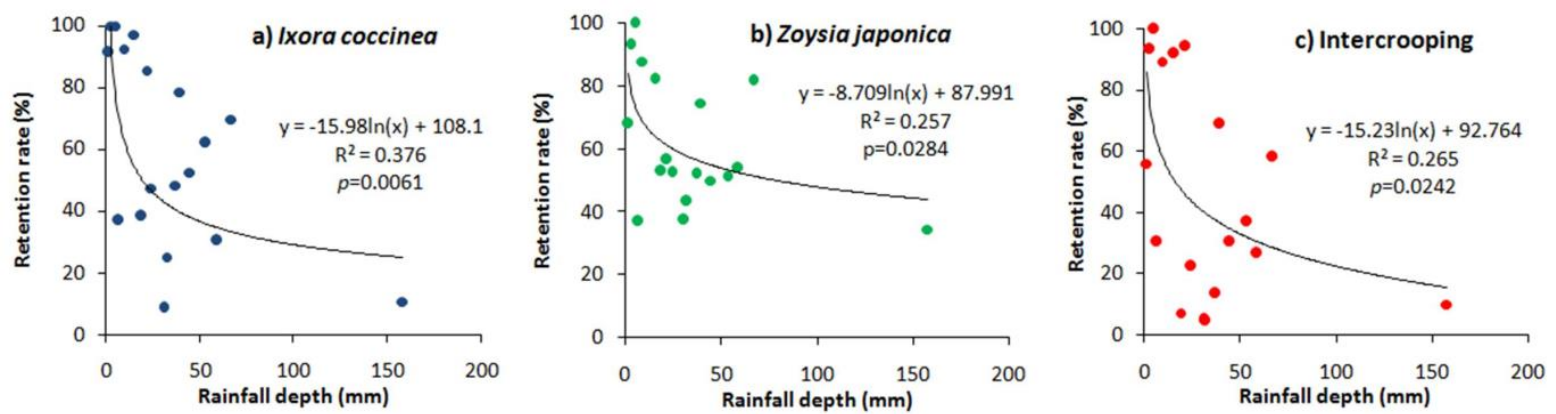

Figure 5 - Regression plot of rainfall duration and retention rate (\%) for (a) I. coccinea green roof, (b) $Z$. japonica green roof and (c) consortium green roof
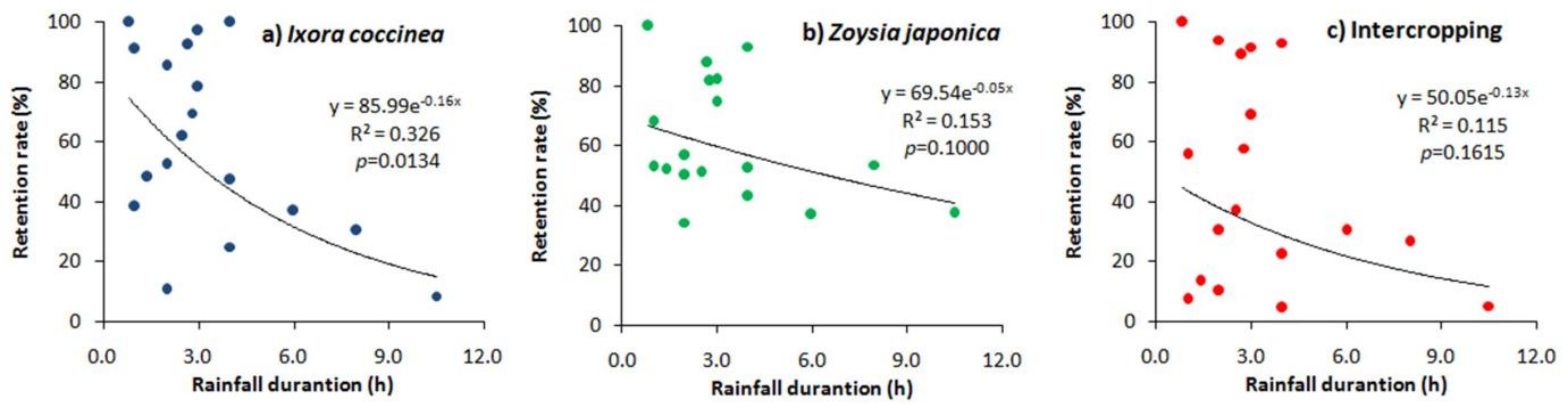

Figure 6 - Regression plot of ADWP and retention rate (\%) for (a) I. coccinea green roof, (b) Z. japonica green roof and (c) consortium green roof
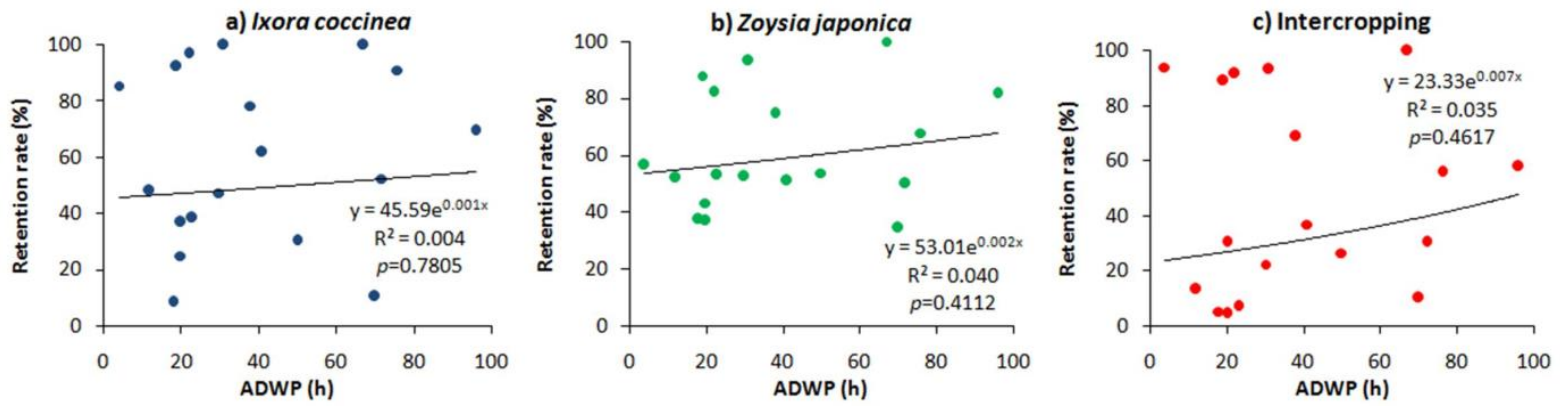


\subsection{Influence of rainfall intensity in retention on green roofs}

The influence of rainfall intensity in green roof retention is shown in Figure 7. Rainfall events were classified according to Zhang et al. (2015) in small rainfall ( $<10.0 \mathrm{~mm})$, medium rainfall $(10.0-24.9 \mathrm{~mm})$, large rainfall $(25.0-49.9 \mathrm{~mm})$ and storm $(>50.0 \mathrm{~mm})$. The events selected for analysis were composed of 5 small, 4 medium, 5 large and 4 storms. There was an inverse relationship between the depths of rainfall and the percentage of that rainfall that was retained; for small rainfall events, 73.8-84.2\% was retained in three green roofs; for medium events, 54.0-67.1\% was retained; for large events, 24.6-51.5\% was retained; and for storms, 33.0-55.3\% was retained. These results were similar to those obtained by Villarreal and Bengtsson (2005), Getter et al. (2007) and Zhang et al. (2015), who found that an inverse relationship existed between the depth of rainfall and capacity of retention by green roofs. These results can be explained based on finite storage capacity of green roofs. A lager rainfall event produces a greater proportion of runoff, when compared to a smaller event (GETTER et $a l ., 2007)$. Likewise, a green roof will retain a greater proportion of rainfall from a smaller event. So the finite storage capacity of a green roof notably restricts its ability to retain rainwater from larger events (STOVIN et al., 2013). The data of rainfall intensity x type of green roof were also statistically analyzed (at 5\% significance level), but no significant results were observed.

Figure 7 - Relationship between rainfall intensity and retention rate by green roofs

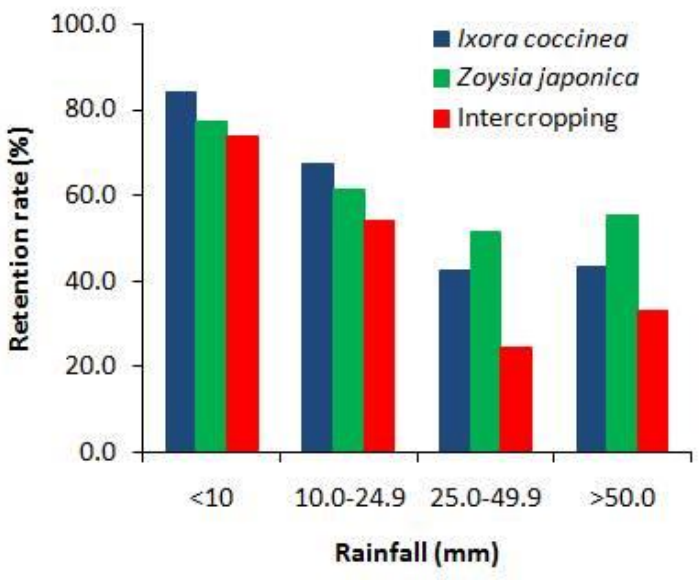

\subsection{Annual green roof runoff retention}

Annual runoff retention volume and the annual retention rates by the green roofs with I. coccinea, Z. japonica and intercropping reached, respectively, $805.8 \mathrm{~mm}$ and $57.3 \%, 838.8$ $\mathrm{mm}$ and $59.7 \%$ and $615.7 \mathrm{~mm}$ and $43.8 \%$ (Table 3). These values are within the range reported in two meta-analysis studies, which reported that extensive green roofs showed annual runoff reduction of 27-81\% (MENTENS et al., 2006) and 16-87\% (SPOLEK, 2008) of annual precipitation. The cumulative retention demonstrates that the green roof can significantly contribute to the total volume of rainwater that might otherwise impact upon watercourses. However, it is critical to have a fuller understanding of the roof's ability to retain and detain flows from larger extreme events, which are more likely to contribute to significant catchment flooding (STOVIN et al., 2012). 
Vacari, Thaisa, et al.; Water quantity investigation of simulated green roofs in a tropical climate: influence of vegetation composition. E\&S Engineering and Science, 2019, 8:2.

Table 3 - Data summary for the mean annual rainfall types, rainfall days $(\mathrm{RD})$, precipitation $(\mathrm{P})$ and green roofs runoff retention rates between 1989 and 2015

\begin{tabular}{|c|c|c|c|c|c|c|c|c|}
\hline \multirow{2}{*}{$\begin{array}{l}\text { Rainfall } \\
\text { type }\end{array}$} & \multirow{2}{*}{$\begin{array}{l}\mathrm{RD}^{*} \\
\text { (days/year) }\end{array}$} & \multirow{2}{*}{$\begin{array}{l}\mathrm{P} * * \\
(\mathrm{~mm})\end{array}$} & \multicolumn{3}{|c|}{ Annual runoff retention $(\%)$} & \multicolumn{3}{|c|}{ Annual runoff retention $(\mathrm{mm})$} \\
\hline & & & $\begin{array}{l}I . \\
\text { coccinea } \\
\text { (shrub) }\end{array}$ & $\begin{array}{l}Z . \\
\text { japonica } \\
\text { (grass) }\end{array}$ & Intercropping & $\begin{array}{l}I . \\
\text { coccinea } \\
\text { (shrub) }\end{array}$ & $\begin{array}{l}Z \text { Z. } \\
\text { japonica } \\
\text { (grass) }\end{array}$ & Intercropping \\
\hline$<10.0$ & 72 & 243.0 & 84.2 & 77.3 & 73.8 & 204.6 & 187.8 & 179.3 \\
\hline $10-24.9$ & 27 & 425.0 & 67.1 & 61.1 & 54.0 & 285.2 & 259.7 & 229.5 \\
\hline $25.0-49.9$ & 12 & 433.0 & 42.6 & 51.5 & 24.6 & 184.5 & 223.0 & 106.5 \\
\hline$>50$ & 4 & 304.3 & 43.2 & 55.3 & 33.0 & 131.5 & 168.3 & 100.4 \\
\hline Total & 115 & 1405.3 & 57.3 & 59.7 & 43.8 & 805.8 & 838.8 & 615.7 \\
\hline
\end{tabular}

* Average annual rainfall days considering the period 1989 and 2015 and rainfall type.

** Average annual precipitation considering the period 1989 and 2015 and rainfall type.

\section{CONCLUSIONS}

The runoff retention by three pilot-scale green roofs with different vegetation based on 18 rainfall events was investigated. Green roofs demonstrated to be efficient tools for decreasing rainwater runoff (46.7-61.6\%) even though the study was carried out in the period of frequent rain events and short ADWPs $(<5$ days $)$. Retention rates varied with rainfall intensity, with the highest retention for small $(<10.0 \mathrm{~mm})$ followed by medium events $(10.0-$ $24.9 \mathrm{~mm}$ ). Annual runoff retention volume and retention rates by green roofs ranged from 615.7 to $838.8 \mathrm{~mm}$ and 43.8 to $59.7 \%$. The difference in retention rates for the types of green roofs (grass, shrub and intercropping of the two plants) was not statistically significant. On the other hand, the substrate could have a decisive influence in rainfall retention. This study has provided evidence of green roof effectiveness at contributing to rainwater management and the data may contribute to the development of policy, regulation, and incentives for widespread green roof implementation in Brazil.

\section{ACKNOWLEDGEMENT}

This study was supported by the Foundation to Research Support of the State of Mato Grosso (FAPEMAT in Portuguese) under Grant 331673/2012.

\section{REFERENCES}

BECK, D. A.; JOHNSON, G. R.; SPOLEK, G. A. Amending greenroof soil with biochar to affect runoff water quantity and quality. Environmental Pollution, v. 159, n. 8-9, p. 21112118, 2011. http://dx.doi.org/10.1016/j.envpol.2011.01.022

BEECHAM, S.; RAZZAGHMANESH, M. Water quality and quantity investigation of green roofs in a dry climate. Water Research, v. 70, p. 370-384, 2015. https://doi.org/10.1016/j.watres.2014.12.015

BERNDTSSON, J. C. Green roof performance towards management of runoff water quantity and quality: A review. Ecological Engineering, v. 36, n. 4, p. 351-360, 2010. http://dx.doi.org/10.1016/j.ecoleng.2009.12.014

BERNDTSSON, J. C.; BENGTSSON, L.; JINNO, K. Runoff water quality from intensive and extensive vegetated roofs. Ecological Engineering, v. 35, n. 3, p. 369-380, 2009. https://doi.org/10.1016/j.ecoleng.2008.09.020 
BESIR, A. B.; CUCE, E. Green roofs and facades: A comprehensive review. Renewable and $\begin{array}{lllll}\text { Sustainable } & \text { Energy } & \text { Reviews, } & \text { v.82, } & \text { p.915-939, }\end{array}$ https://doi.org/10.1016/j.rser.2017.09.106

BUCKLAND-NICKS, M.; HEIM, A.; LUNDHOLM, J. Spatial environmental heterogeneity affects plant growth and thermal performance on a green roof. Science of the Total

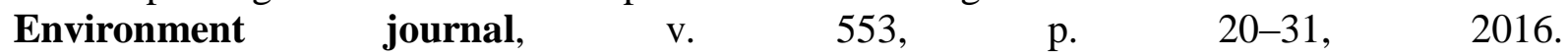
https://doi.org/10.1016/j.scitotenv.2016.02.063

BUCCOLA, N.; SPOLEK, G. A pilot-scale evaluation of greenroof runoff retention, detention, and quality. Water, Air, \& Soil Pollution, v. 216, n. 1-4, p. 83-92, 2011. https://doi.org/10.1007/s11270-010-0516-8

CARSON, T. B.; MARASCO, D. E.; CULlIGAN, P. J.; MCGILlIS, W. R. Hydrological performance of extensive green roofs in New York City: observations and multi-year modeling of three full-scale systems. Environmental Research Letters, v. 8, n. 2, p. 24036, 2013. https://doi.org/10.1088/1748-9326/8/2/024036

CATALANO, C.; MARCENÒ, C.; LAUDICINA, V. A.; GUARINO, R. Thirty years unmanaged green roofs: Ecological research and design implications. Landscape and Urban Planning, v. 149, p. 11-19, 2016 https://doi.org/10.1016/j.landurbplan.2016.01.003

DUNNETT, N.; NAGASE, A.; BOOTH, R.; GRIME, P. Influence of vegetation composition on runoff in two simulated green roof experiments. Urban Ecosystems, v. 11, n. 4, p. 385398, 2008. https://doi.org/10.1007/s11252-008-0064-9

FANG, C. F. Evaluating the thermal reduction effect of plant layers on rooftops. Energy and Buildings, v. 40, n. 6, p. 1048-1052, 2008. https://doi.org/10.1016/j.enbuild.2007.06.007

GETTER, K. L.; ROWE, D. B.; ANDRESEN, J. A. Quantifying the effect of slope on extensive green roof stormwater retention. Ecological Engineering, v. 31, n. 4, p. 225-231, 2007. https://doi.org/10.1016/j.ecoleng.2007.06.004

GREGOIRE, B. G.; CLAUSEN, J. C. Effect of a modular extensive green roof on stormwater runoff and water quality. Ecological Engineering, v. 37, n. 6, p. 963-969, 2011. http://dx.doi.org/10.1016/j.ecoleng.2011.02.004

HARPER, G. E.; LIMMER, M. A.; SHOWALTER, W. E.; BURKEN, J. G. Nine-month evaluation of runoff quality and quantity from an experiential green roof in Missouri, USA. $\begin{array}{llllll}\text { Ecological } & \text { Engineering, } & \text { v. } & 78, & \text { p. } & 127-133,\end{array}$ https://doi.org/10.1016/j.ecoleng.2014.06.004

HASHEMI, S. S. G.; MAHMUD, H. B.; ASHRAF, M. A. Performance of green roofs with respect to water quality and reduction of energy consumption in tropics: A review. Renewable and Sustainable Energy Reviews, v. 52, p. 669-679, 2015. https://doi.org/10.1016/j.rser.2015.07.163

LEE, J. Y.; LEE, M. J.; HAN, M. A pilot study to evaluate runoff quantity from green roofs. Journal of Environmental Management, v. 152, p. 171-176, 2015. http://dx.doi.org/10.1016/j.jenvman.2015.01.028 
LUNDHOLM, J.; MACIVOR, J. S.; MACDOUGALL, Z.; RANALLI, M. Plant species and functional group combinations affect green roof ecosystem functions. PLoS ONE, v. 5, n. 3, e9677, 2010. https://doi.org/10.1371/journal.pone.0009677

MENTENS, J.; RAES, D.; HERMY, M. Green roofs as a tool for solving the rainwater runoff problem in the urbanized 21st century? Landscape and Urban Planning, v. 77, n. 3, p. 217226, 2006. https://doi.org/10.1016/j.landurbplan.2005.02.010

MONTERUSSO, M. A.; RUSSELL, D. K.; RUGH, C. L. Runoff water quantity and quality from green roof systems. Acta Horticulturae, v. 639, p. 369-376, 2004. http://dx.doi.org/10.17660/ActaHortic.2004.639.49

NAGASE, A.; DUNNETT, N. Amount of water runoff from different vegetation types on extensive green roofs: Effects of plant species, diversity and plant structure. Landscape and
Urban
Planning,
v. 104 ,
n. 3-4,
p. $356-363$,
2012.

http://dx.doi.org/10.1016/j.landurbplan.2011.11.001

NAWAZ, R.; McDONALD, A.; POSTOYKO, S. Hydrological performance of a full-scale extensive green roof located in a temperate climate. Ecological Engineering, v. 82, p. 66-80, 2015. http://dx.doi.org/10.1016/j.ecoleng.2014.11.061

PARIZOTTO, S.; LAMBERTS, R. Investigation of green roof thermal performance in temperate climate: A case study of an experimental building in Florianópolis city, Southern Brazil. Energy and Buildings, v. 43, n. 7, p. 1712-1722, 2011. http://dx.doi.org/10.1016/j.enbuild.2011.03.014

RAZZAGHMANESH, M.; BEECHAM, S. The hydrological behaviour of extensive and intensive green roofs in a dry climate. Science of the Total Environment, v. 499, n. 1, p. 284-296, 2014. http://dx.doi.org/10.1016/j.scitotenv.2014.08.046

SIMMONS, M. T.; GARDINER ,B.; WINDHAGER, S.; TINSLEY, J. Green roofs are not created equal: The hydrologic and thermal performance of six different extensive green roofs and reflective and non-reflective roofs in a sub-tropical climate. Urban Ecosystems, v. 11, n. 4, p. 339-348, 2008. http://dx.doi.org/10.1007/s11252-008-0069-4

SPEAK, A. F.; ROTHWELL; J. J.; LINDLEY, S. J.; SMITH, C. L. Rainwater runoff retention on an aged intensive green roof. Science of the Total Environment, v. 461-462, p. 28-38, 2013. http://dx.doi.org/10.1016/j.scitotenv.2013.04.085

SPOLEK, G. Performance monitoring of three ecoroofs in Portland, Oregon. Urban Ecosystems, v. 11, n. 4, p. 349-359, 2008. http://dx.doi.org/10.1007/s11252-008-0061-z

STOVIN, V.; VESUVIANO, G.; KASMIN, H. The hydrological performance of a green roof test bed under UK climatic conditions. Journal of Hydrology, v. 414-415, p. 148-161, 2012. http://dx.doi.org/10.1016/j.jhydrol.2011.10.022

STOVIN, V.; POË, S.; BERRETTA, C. A. modelling study of long term green roof retention performance. Journal of Environmental Management, v. 131, p. 206-215, 2013. https://doi.org/10.1016/j.jenvman.2013.09.026 
TZOULAS, K,; KORPELA, K.; VENN, S.; YLI-PELKONEN, V.; KAŹMIERCZAK, A.; NIEMELA, J.; JAMES, P. Promoting ecosystem and human health in urban areas using Green Infrastructure: A literature review. Landscape and Urban Planning, v. 81, p. 167178, 2007. http://dx.doi.org/10.1016/j.landurbplan.2007.02.001

Van RENTERGHEM, T.; BOTTELDOOREN, D. Reducing the acoustical façade load from road traffic with green roofs. Building and Environment, v. 44, n. 5, p. 1081-1087, 2009. http://dx.doi.org/10.1016/j.buildenv.2008.07.013

VanWOERT, N. D.; ROWE, D. B.; ANDRESEN, J. A.; RUGH, C. L.; FERNANDEZ, R. T.; XIAO, L. Green roofs stormwater retention: effects of roof surface, slope, and media depth. Journal of Environmental Quality, v. 34, n. 3, p. 1036-1044, 2005. http://dx.doi.org/10.2134/jeq2004.0364

VANUYTRECHT, E.; Van MECHELEN, C.; Van MEERBEEK, K.; WILLEMS, P.; HERMY, M.; RAES, D. Runoff and vegetation stress of green roofs under different climate change scenarios. Landscape and Urban Planning, v. 122, p. 68-77, 2014. http://dx.doi.org/10.1016/j.landurbplan.2013.11.001

VIJAYARAGHAVAN, K.; RAJA, F. D. Design and development of green roof substrate to improve runoff water quality: Plant growth experiments and adsorption. Water Research, v. 63, p. 94-101, 2014. http://dx.doi.org/10.1016/j.watres.2014.06.012

VILLARREAL, E. L.; BENGTSSON, L. Response of a Sedum green-roof to individual rain $\begin{array}{llllll}\text { events. Ecological } & \text { Engineering, } & \text { v. 25, } & \text { n. 1, } & \text { p. 1-7, }\end{array}$ http://dx.doi.org/10.1016/j.ecoleng.2004.11.008

VOLDER, A.; DVORAK, B. Event size, substrate water content and vegetation affect storm water retention efficiency of an un-irrigated extensive green roof system in Central Texas. $\begin{array}{llllll}\text { Sustainable Cities and } & \text { Society, } & \text { v. 10, 59-64, }\end{array}$ http://dx.doi.org/10.1016/j.scs.2013.05.005

VOYDE, E; FASSMAN, E.; SIMCOCK, R. Hydrology of an extensive living roof under sub-tropical climate conditions in Auckland, New Zealand. Journal of Hydrology, v. 394, n. 3-4, p. 384-395, 2010. http://dx.doi.org/10.1016/j.jhydrol.2010.09.013

WONG, G. K. L.; JIM, C. Y. Identifying keystone meteorological factors of green-roof stormwater retention to inform design and planning. Landscape and Urban Planning, v. 143, p. 173-182, 2015. http://dx.doi.org/10.1016/j.landurbplan.2015.07.001

YANG, J.; YU, Q.; GONG, P. Quantifying air pollution removal by green roofs in Chicago. $\begin{array}{lllll}\text { Atmospheric } & \text { Environment, } & \text { v. 42, } & \text { n. 31, } & \text { p. 7266-7273, }\end{array}$ https://doi.org/10.1016/j.atmosenv.2008.07.003

ZHANG, Q.; MIAO, L.; WANG, X.; LIU, D.; ZHU, L.; ZHOU, B.; SUN, J.; LIU, J. The capacity of greening roof to reduce stormwater runoff and pollution. Landscape and Urban Planning, v. 144, p. 142-150, 2015. http://dx.doi.org/10.1016/j.landurbplan.2015.08.017 